\title{
Analisis User Interface pada Media Pembelajaran Bahasa Inggris Berbasis Game Visual Novel
}

\author{
D. Deli \\ * Sistem Informasi, Universitas Internasional Batam \\ deli@uib.ac.id
}

\begin{tabular}{l} 
Article Info \\
\hline Article history: \\
Received 04-01-2021 \\
Revised 29-01-2021 \\
Accepted 03-02-2021 \\
\hline
\end{tabular}

Keyword:

Learning Media,

User Interface,

Usability,

Heuristic Evaluation,

Visual Novel.

\begin{abstract}
Heuristic evaluation in applicating of system evaluation is considered capable of being used in analyzing and testing the level of ease in operating visual-based English novel as learning media. The evaluation does not limit the assessment and measurement of the level of usability of the system by involving end users in the work and testing process. Therefore, heuristic evaluation is needed to determine how high the usability level of English learning media based on visual novels in the use of learning media. The research sample was aimed at the first semester of Information System department's students to provide an assessment of user interface of the learning media using probability sampling, proportionate stratified random sampling as the focus of the sampling technique that will fill out the questionnaire. The data in the study will be analyzed using a mix of qualitative and quantitative descriptive analysis methods. Based on the results of the study, it is stated that the visual-based English novel learning media interface layout design will be able to meet the criteria for heuristic evaluation and has good usability criteria and is easy to operate by users.
\end{abstract}

\section{Pendahuluan}

Interaksi manusia dan komputer merupakan salah satu ilmu yang berfokus pada perencanaan dan desain sebuah sistem agar pengguna mampu berinteraksi dan bekerjasama sesuai dengan kebutuhan pengguna itu sendiri dengan cara paling efektif pada setiap Langkah kerjanya. Salah satu interaksi yang bisa dugunakan oleh pengguna terhadap computer adalah tampilan antarmuka/user interface (UI) yang dapat dilihat, disentuh, diajak berbicara secara langsung maupun tidak dengan tingkat pemahaman yang telah ditentukan sebelumnya oleh perancang sistem.

User Interface (UI) merupakan salah satu bagian penting dalam perancangan sebuah sistem, selain sebagai bagian terpenting dalam interaksi antar manusia dan komputer UI juga berpengaruh dalam daya tarik sebuah tampilan [1] Setiap detail yang muncul seperti tulisan, gambar, petunjuk dan tombol merupakan bagian dari sebuah UI. User interface tentu tidak dielakkan lagi menjadi bagian penting dari sebuah perangkat lunak, termasuk pada media pembelajaran interaktif yang bisa diajak berkomunikasi secara langsung dengan proses pemahaman tertentu untuk menjadi jembatan penghubung pengguna dengan komputer dalam menyelesaikan sebuah masalah, maka penting untuk mengalisis perancangan sebuah user interface guna mampu untuk memberikan user experience yang baik bagi pengguna selama menggunakan sebuah aplikasi [2].

Media pembelajaran digital atau yang lebih dikenal dengan istilah e-learning merupakan salah satu metode penyampaian materi ajar berbasis teknologi yang berfungsi sebagai media dalam pengajaran, pelatihan dan proses belajar dimana dan kapanpun berada [3]. Pembelajaran berbasis $e$-learning terdiri dari berbagai jenis domain teknologi seperti mendesain, pengembangan, pemanfaan dan pengelolaan. Dipandang dari segi efektif dan efisien, maka proses pelaksanaan E-learning sendiri banyak memanfaatkan bantuan smartphone dalam pengaplikasiannya sehingga tidak menutup kemungkinan begitu banyak aplikasi pembelajaran yang muncul dengan tampilan antarmuka yang menarik perhatian para penggunaanya agar betah berlama-lama mengoperasikan aplikasi pembelajaran tersebut.

Pengembangan media pembelajaran berbasis game maupun online tidak dipungkiri sudah berkembang dengan sangat pesat, salah satu acuan penelitian yang dituju berfokus terhadap analisis pada desain user interface pada W3school dengan focus memiliki kriteria sistem informasi seperti efektif, efisien, menarik, toleransi kelasalahan yang dibuat oleh pengguna dan tentu kemudahan dalam menggunakan. 
Pemenuhan kriteria tersebut mampu menumbuhkan user experience yang baik bagi penggunanya selama mengakses media pembalajaran jarak jauh, dengan demikian acuan analisis yang dilakukan mampu mnejadi pegangan bagi pihak pengembang untuk mempersiapkan media pembelajaran lebih menarik lagi dan mampu bertahan sesuai kebutuhan [4].

Aplikasi pembelajaran Bahasa Inggris berbasis game merupakan salah satu jenis aplikasi yang digunakan untuk membantu pengguna dalam belajar bahasa inggris secara online namun menarik, tentu aplikasi yang mendukung proses pembelajaran bahasa inggris menjadi lebih menyenangkan dengan alur cerita dan konten fungsi pada UI yang lengkap. Hal ini memunculkan ketertarikan dalam melakukan penelitian terhadap UI aplikasi pembelajran bahasa inggris ini untuk mengetahui komponen desain UI yang digunakan menurut sisi pengguna. Beberapa komponen yang akan dilakukan analisis lebih lanjut terkait dengan layout konten, pemilihan warna dan kontrol termasuk pada fungsi dan fitur yang disajikan pada media pembelajaran ini.

Penelitian serupa dilakukan pada media pembelajaran berbasis game edukatif [5] yang berfokus pada menganalisis user interface memunculkan pendapat dan hasil user interface merupakan elemen vital dalam sebuah tampilan game yang dimana user interface bersifat estetik juga harus memiliki unsur fungsionalitas yang memadai pula, sehingga mampu menciptakan user experience pengguna menjadi lenbih baik selama menggunakan medi pembelajaran.

Berdasarkan dengan pemaparan latar belakang masalah diatas, maka peneliti akan melakukan analisis terhadap UI pada media pembelajaran Bahasa inggris berbasis visual novel dengan menggunakan metode Heuristik.

\section{TINJAUAN PUSTAKA}

Pelaksanaan penyusunan proposal penelitian ini, didukung dengan jurnal-jurnal penelitian sebelumnya yang telah pernah dilaksanakan oleh para ahli dibidangnya dirasa diperlukan guna untuk menjadi acuan dan pedoman bagi penulis dimasa ini agar tidak mengurangi nilai yang terkandung didalamnya.

Penelitian pertama yang pernah dilakukan oleh [6] fokus penelitian dilakukan pada pengujian usability antarmuka Game Jungle of Ikki yang merupakan penelitian evaluative dengan cara mengevaluasi usability user antarmuka. Melalui penyebaran kuesioner pada kurang lebih pengujian pada 52 anak dengan rentang usia 9-12 tahun menggunakan tiga tahapan yaitu identifikasi masalah, pengembangan dan penarikan kesimpulan. Hasil penelitian evaluasi pada tahap pertama didapatkan $32 \%$ responden menjawab sangat setuju terhadap indicator yang diprioritaskan dalam penilaian terhadap prioritas pengembangan pada perbaikan desian tampilan antarmuka game, maka demikian penelitian dapat disimpulkan hasil diperoleh $30 \%$ usability terpenuhi dalam pengembangan dan evaluasi rancangan antarmuka dengan menggunakan heuristic evaluation.

Penelitian yang kedua dilakukan oleh [7] dengan focus terhadap analisis pada user interface dan user experience pada game perang komando dengan menggunakan metode heuristic evaluation. Penelitian dilakukan dengan tujuan pada pengukuran terhadap sejauh mana kepuasan dan kenyamanan pengguna dalam penggunaannya dengan melalui pengujian usability dilengkapi dengan metode single ease question yang digunakan agar mampu mengukur kemudahan penggunaan dan tentu mampu memberikan tampilan antarmuka yang memuaskan bagi pengguna selama menggunakan aplikasi. Hasil penelitian didapatkan nilai rata-rata 6,6 yang secara keseluruhan mampu dinyatakan game berjalan dengan lancer dan fungsi yang mudah dioperasikan, sehingga kesimpulan akhir menyatakan bahwa game mampu memberikan kepuasan pengguna selama bermain dengan tampilan antarmuka yang telah dirancang.

Penelitian ketiga dilakukan oleh [8] dengan fokus penelitian pada game novel visual berbasis android menggunakan extreme programming dengan hasil pengujian menggunakan blackbox dengan hasil yang sesuai terhadap penilaian pengguna aplikasi, dengan penilaian fungsi, informasi dan kemudahan pengoperasian aplikasi secara keseluruhan bekerja dengan baik.

Penelitian keempat dilakukan oleh para peneliti [9] dengan fokus penelitian pada pengembangan media pembelajaran animasi 3 dimensi pada anatomi tubuh Manusia berbasis android dengan menggunakan metode multimedia development life cycle dan model penelitian kuantitatif deskriptif melalui penyebaran angket. Pengujian dilakukan dengan indicator usability testing berdasarkan pada lima jenis komponen yaitu learnbility, efficiency, memorability, errors dan tentunya satisfaction pengguna selama menggunakan aplikasi pembelajaran. Hasil akhir penelitian didapatkan peningkatan sebesar $87 \%$ pada ketertarikan dan peningkatan hasil belajar setelah menggunakan aplikasi pembelajaran berbasis android.

Penelitian kelima dilaksanakan oleh [10] dengan fokus penelitian terkait dengan analisis pada desain antarmuka pembelajaran online menggunakan evaluasi heuristic, yang dimana dilakukan pengujian terhadap desain antarmuka media pembelajaran dengan melalui tahapan pengujian 10 kriteria kemudahan penggunaan dan mampu memenuhi standar tersebut sebagai sebuah portal akademik pembelajaran.

Berdasarkan dengan kutipan lima jurnal dengan penelitian serupa, maka dinilai mampu menganalisis sebuah tampilan antarmuka pada sebuah sistem dan aplikasi yang dianggap user friendly dan memenuhi kriteria usability terhadap pengguna selama mengoperasikan sistem, dengan demikian harapan mampu membantu peneliti dalam memperbaiki sistem kedepannya.

\section{METODE PENELITAN}

Metode penelitian yang diterapkan adalah menggunakan metode pengujian Heuristik dengan penilaian 10 kriteria usability [11] yang baik dalam membantu peneliti dalam melakukan pengujian terhadap pencarian kesalahan dan solusi pada tampilan antarmuka aplikasi yang telah dirancang 
dan tentunya agar kedepan kemudahan penggunaan merupakan tujuan awal daripada penelitian ini dilakukan.

\section{A. Aspek Evaluasi Heuristik}

Analisis sistem yang dilakukan pada penelitian ini bertujuan untuk mengetahui seberapa jauh kebutuhan komponen yang mampu untuk mengidentifikasi dan mengevaluasi permasalahn yang sedang dihadapi, dan analisis sendiri menjadi salah satu arahan untuk mendapatkan pemahaman yang sama berdasarkan pada si perancang sistem dan pihak pengguna aplikasi [12].

Dalam penyelesaian penelitian ini tidak luput dari tahapantahapan pada metodologi yang akan diterapkan, yaitu yang akan dilaksanakan pada tahap sebagai berikut [13]:

1. Visibilitas Status Sistem, pada umumnya tahap pertama merupakan melakukan pengujian terhadap sistem terkait pada pemberian informasi kepada pengguna mengenai apa yang sedang terjadi saat ini dengan melalui pesan feedback yang baik dan tepat.

2. Kecocokan antara sistem dengan dunia nyata, yaitu menguji bahwa sistem mampu berbicara dengan pengguna dengan menggunakan kalimat dan Bahasa yang mudah dimengerti dan sesuai dengan konsep pengguna.

3. Kontrol pengguna dan kebebasan, tahap ini menguji kebenaran terhadap sistem apakah mampu memberikan pengguna rasa bebas dalam memilih dan melakukan pekerjaan sesuai dengan kebutuhan hingga tahap pengguna mampu melakukan kontrol undo dan redo selama penggunaan sistem.

4. Konsistensi dan Standar, suatu antarmuka mampu dikatakan memiliki ciri-ciri konsisten dalam tampilan sehingga mampu meminimalisir keraguan pengguna selama menggunakan sistem.

5. Pengecekan kesalahan, sebuah sistem yang dianggap baik adalah yang mampu membuat pengguna dalam menghindari sebuah kesalahan salama penggunaan sistem, maka pencegahan dalam kesalahan sistem sangat perlu diperhatikan sebelum dan selama pengguna menggunakan sistem tersebut.

6. Pengenalan atas penarikan kembali, pengguna tidak ragu dan bingung terhadap pemahaman kalimat, kata maupun sebuah aksi dalam sistem.

7. Fleksibilitas dan efisiensi, sebuah sistem mampu dijadikan sebagai akomodasi pengguna yang sudah ahli maupun pengguna pemula. Sehingga diperlukan adanya ketegori pengguna.

8. Keindahan dan desain minimalis, sebuah sistem mampu menampilkan dan memberikan informasi dan pesan yang relevan terhadap kebutuhan pengguna.

9. Bantuan bagi pengguna untuk mengenali, mendiagnosis dan memperbaiki dari kesalahan. Dengan menunjukkan sebuah masalah yang muncul dan mampu memberikan saran sebuah solusi bagi pengguna.

10. Bantuan dan dokumentasi, sistem yang baik dianggap perlu adanya sebuah pedoman bagaimana mengoperasikan sistem, sehingga mampu membantu pengguna mempelajari sistem secara mandiri dengan cepat dan mudah.

\section{B. Usability Testing}

Pengujian kegunaan merupakan langkah mengukur tingkat efisiensi, kemudahan dalam mengoperasikan dan serta kemampuan dalam mengingat bagaimana cara berinteraksi dengan tanpa melakukan kesalahan, menguji seberapa mudah sebuah antarmuka sistem digunakan oleh pengguna [14]. Berikut beberapa langkah dalam melaksanakan pengujian:

1. Memilih objek, langkah awal penentuan objek yang akan diteliti

2. Memilih responden untuk melakukan pengisian kuesioner dengan kesesuaian kriteria dan sample terpilih

3. Melakukan presentasi tugas yang harus dilakukan oleh responden, tentu dalam hal ini harus dijelaskan bahwa pengujian dilakukan terhadap sistem bukan penggunanya

4. Memberikan penugasan pada responden yaiut terkait dengan butir-butir peertanyaan dalam kuesioner terlampir

5. Pengisian kuesioner yang dilakukan oleh responden dilakukan dengan secara alami yaitu menjawab sesuai dengan apa yang dirasakan selama responden menggunakan dan mengoperasikan sistem

6. Melakukan Analisa terhadap jawaban yang telah diisi oleh responden setelah mengoperasikan sistem

7. Melaksanakan evaluasi terhadap kekurangan dan kelebihan sistem sesuai dengan hasil kuesioner yang diisi oleh responden

8. Setelah melakukan evaluasi, tahapan berikutnya adalah mempu tercetusnya sebuah rekomendasi dalam tahap pengemabangan sistem selanjutnya.

\section{Tahapan Perancangan}

Pada tahapan perancangan yang dilaksanakan pada penelitian ini adalah dengan melakukan pengumpulan data kepada para responden yang dipilih dengan menggunakan metode analisis perpaduan kualitatif dan kuantitatif [15] dengan penarikan sampling menggunakan probability sampling, proportionate stratified random sampling [16], perhitungan menggunakan rumus slovin [17] maka yang didapatkan dari total populasi mahasiswa semester satu kelas Desain Interaksi sebanyak 180 mahasiswa dengan confidence level sebesar 95\% dan margin of error sebesar 5\% ada perhitungannya ditentukan sebanyak 123 responden yang akan berpartisipasi dalam memberikan penilaian terhadap user interface media pembelajaran bahasa inggris berbasis visual novel yang telah dirancang. Jumlah responden terpilih dianggap mampu memberikan input yang positif terhadap rancangan UI aplikasi.

\section{Perancangan Kuesioner}

Perancangan dan penggunaan kuesioner digunakan dalam melakukan pendataan terhadap hasil masukan dari para pengguna selama menganalisis user interface media 
pembelajaran. Perancangan kuesioner [18] dilakukan dengan dua jenis yaitu kuesioner perancangan bersifat kualitatif dengan fokus pada penilaian perancangan UI media pembelajaran dan kuantitatif dengan fokus penilaian dengan menggunakan skala likert 1-5 dengan skala sangat setuju (5); setuju (4); cukup setuju (3); kurang setuju (2); tidak setuju (1). Perancangan pertanyaan yang diajukan dalam survey melalui kuesioner tersebut berlandaskan dengan sepuluh prinsip dasar evaluasi heuristic terhadap penilaian UI media pembelajaran, dengan perwakilan disetiap bobot pertanyaannya agar mampu memberikan gambaran dan penilaian UI media pembelajaran.

\section{PEMBAHASAN DAN HASIL}

Metode penelitian yang dilakukan menggunakan metode analisis kuantitatif dan kualitatif dengan penyeberan kuesioner penilaian pada 123 responden, Adapun pertanyaan dalam penilaian UI media pembelajaran Bahasa Inggris berprinsip pada butir pertanyaan penilaian Heuristik Evaluasi pada pelaksanaan penyebaran kusioner dengan metode analisis kualitatif dan penggunaan metode analisis kuantitatif dengan butir pertanyaan usability sistem. Pada Gambar 1 jumlah keseluruhan responden pengisian dan penilaian terhadap UI pada media pembelajaran Bahasa Inggris, diisi sebanyak 123 responden.

\section{A. Hasil Penyebaran Kuesioner, Metode Kuantitatif}

Berikut penjelasan hasil penyebaran kuesioner dengan penerapan metode kuantitatif user interface media pembelajaran Bahasa inggris.

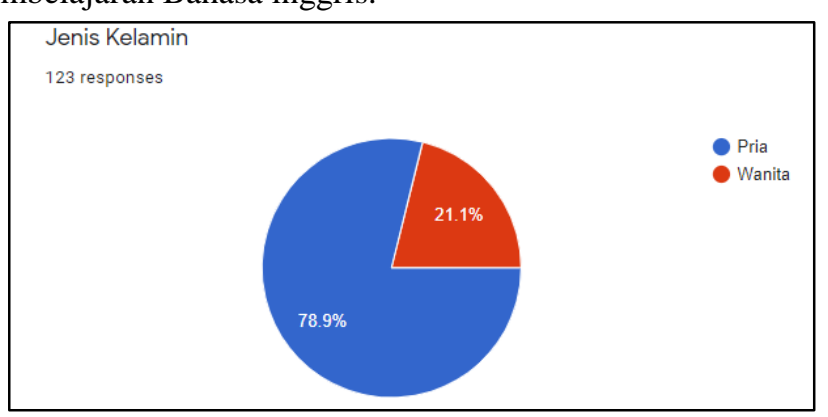

Gambar 1.Diagram Kriteria Jenis Kelamin Responden

Rentang usia yang mengisi dan mencoba media pembelajaran Bahasa inggris rata-rata usia 17-25 tahun. Pada Gambar 2 penelitian yang melibatkan teman mahasiswa semester 1 kelas Desain Interaksi, penilaian dan uji coba sistem dan penilaian dilakukan secara langsung setelah responden menggunakan aplikasi pembelajaran tersebut.

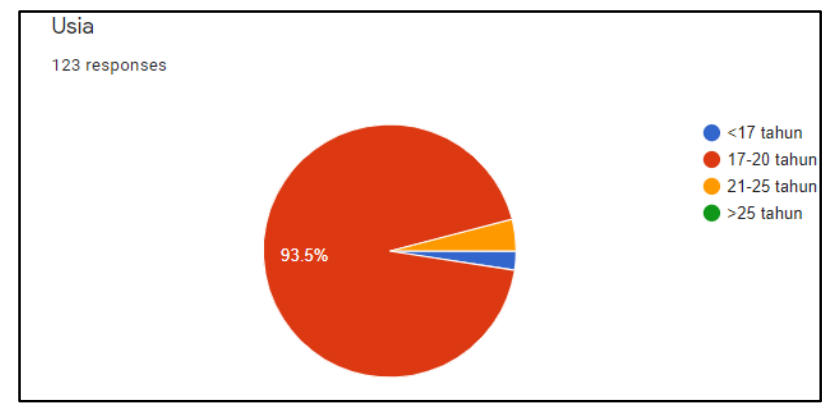

Gambar 2. Diagram Kriteria Usia Responden

Pada Gambar 3 didapatkan hasil pada pengisian kuesioner dengan bentuk penyataan berprinsip pada usability testing, maka diperoleh nilai rata-rata penerimaan pengguna senang untuk menggunakan media pembelajaran berulangkali adalah rata-rata sebesar 3.40 skala diperoleh diatas 3 dinyatakan bahwa para responden penilaian pada poin butir pernyataan pertama "tampilan aplikasi pembelajaran demikian membuat saya ingin sering menggunakannya" adalah cukup setuju.

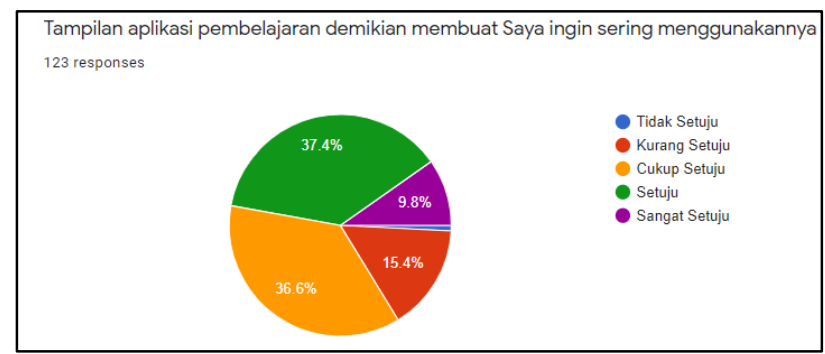

Gambar 3. Diagram Ketertarikan Menggunakan Ulang Aplikasi

Pada Gambar.4 dengan pernyataan "saya melihat ada bagian fitur aplikasi yang cukup merepotkan, yang mestinya tidak perlu terjadi" memperoleh skala penilaian dari responden rata-rata sebesar 2.03 dengan nilai kurang setuju bahwa media pembelajaran adalah kurang merepotkan pengguna selama menggunakan aplikasi tersebut.

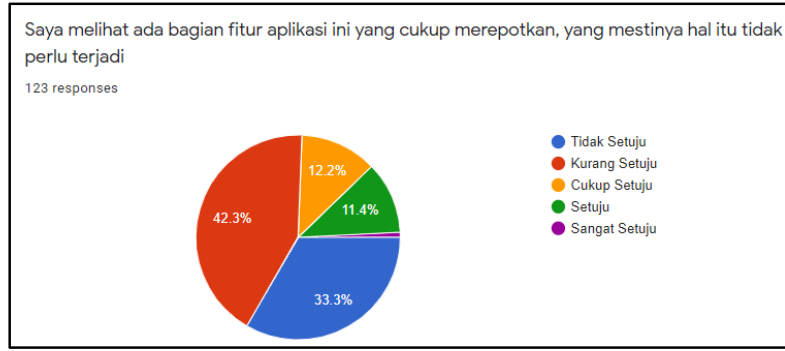

Gambar 4. Diagram Kelengkapan Fitur Aplikasi

Pada Gambar.5 butir pernyataan membahas mengenai "saya merasa aplikasi ini mudah digunakan" memperoleh penilaian pada skala rata-rata 4.30 , skala 4 yaitu reponden merasa setuju media pembelajaran mudah digunakan. 


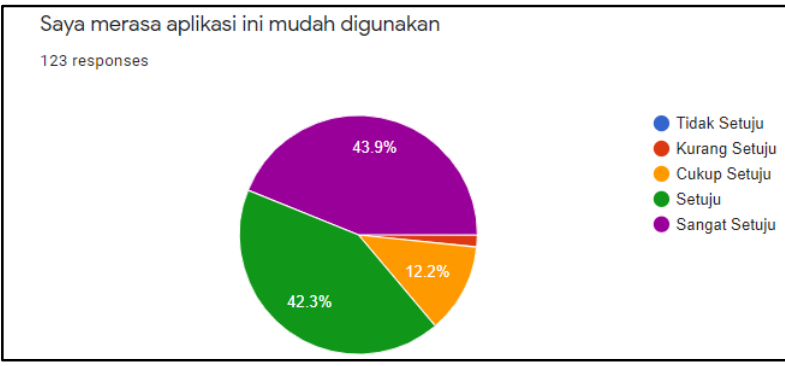

Gambar 5. Diagram Kemudahan Penggunaan Aplikasi

Pada Gambar.6 dengan butir pernyataan "saya merasa membutuhkan bantuan teknisi selama menggunakan aplikasi ini" memperoleh penilaian pada skala rata-rata 1.60 yang dimana pengguna merasa tidak setuju membutuhkan teknisi khusus membantu dalam penggunakaan media pembelajaran.

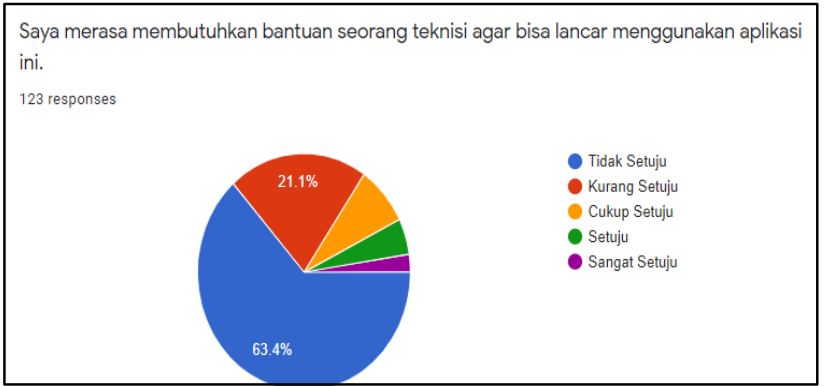

Gambar 6. Diagram Kebutuhan Teknisi Selama Menggunakan Aplikasi

Pada Gambar.7 butir pernyataan "saya merasa fitur-fitur aplikasi sudah terintegrasi dengan baik" memperoleh penilaian pengguna pada rata-rata 4.00 yang berarti pengguna setuju dengan fitur yang tersedia pada media pembelajaran sudah terintegrasi dan terhubung dengan baik satu sama lainnya selama penggunaan.

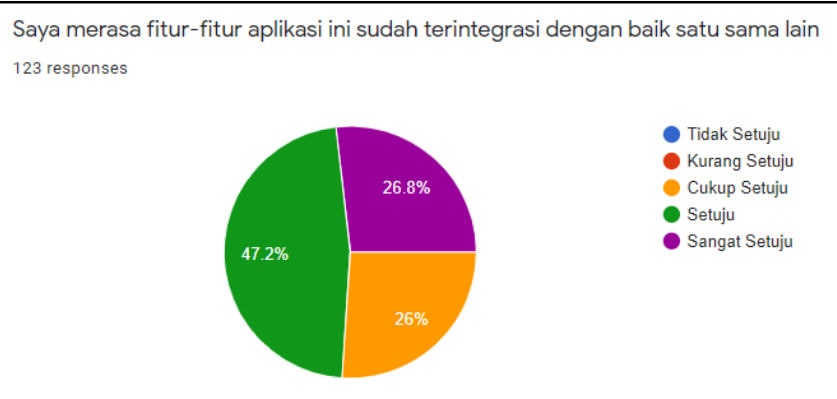

Gambar 7. Diagram Keintegrasian Fitur dalam Aplikasi

Pada butir pernyataan "saya menemukan terlalu banyak ketidakkonsistenan dalam aplikasi ini" dilihat pada diagram hasil olah data Gambar.8 yaitu dengan nilai rata-rata 1.94 yaitu pengguna merasa tidak setuju dalam artian maka media pembelajaran memiliki konsistensi yang baik.

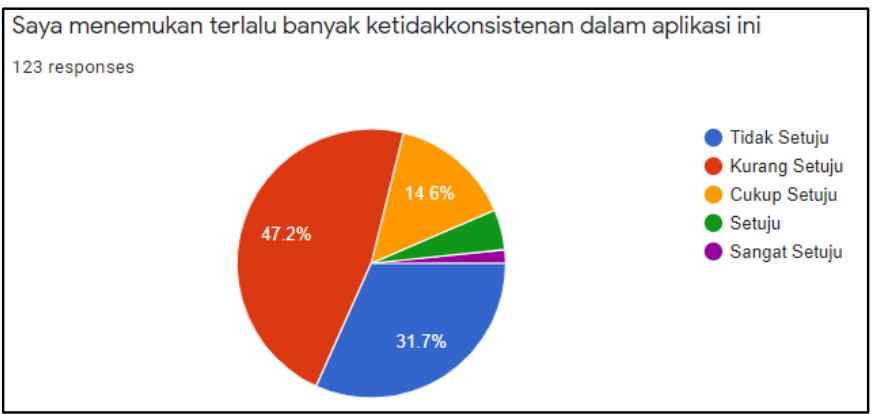

Gambar 8. Diagram Kekonsistenan dalam UI Aplikasi

Pada Gambar.9 dengan butir pernyataan "saya merasa orang akan sengat cepat untuk bisa mengoperasikan aplikasi ini", maka mendapatkan penilaian dari responden selaku pengguna media pembelajaran dengan rata-rata poin 4.0 yaitu pengguna setuju bahwa pengguna akan sangat cepat untuk bisa menggunakan aplikasi secara mandiri.

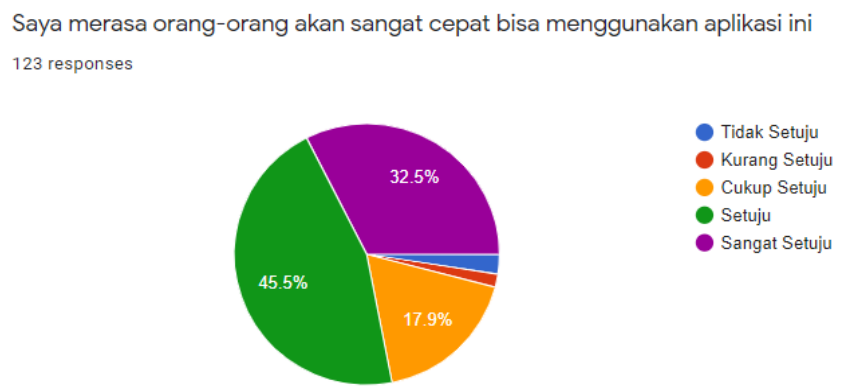

Gambar 9. Diagram Kelengkapan Fitur Aplikasi

Pada Gambar.10 fokus pada penilaian butir pernyataan terhadap "kesulitan pengguna Ketika menggunakan aplikasi" memperoleh poin penilaian pada skala 1.38 , maka pernyataan pengguna bahwa merasa tidak setuju bahwa media pembelajaran sulit digunakan dan dioperasikan.

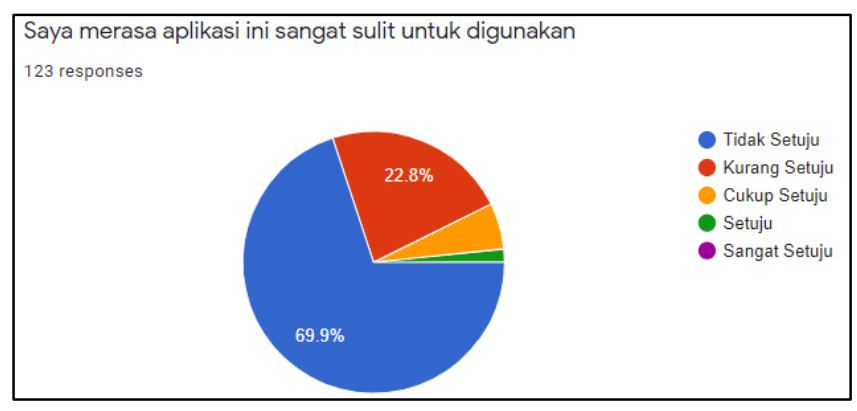

Gambar 10. Diagram Kelengkapan Fitur Aplikasi 


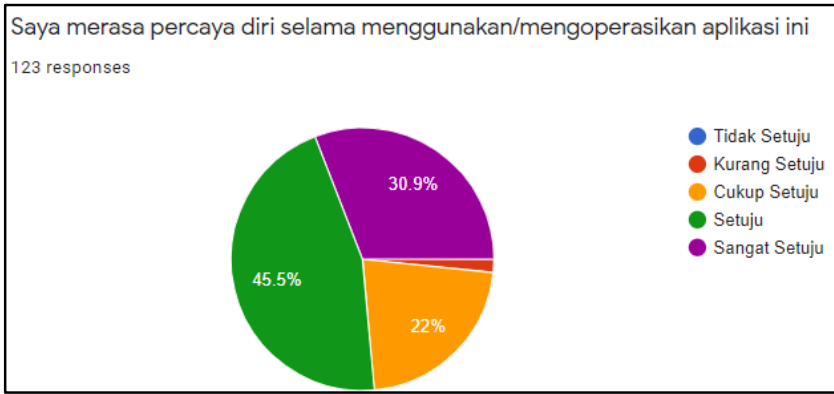

Gambar 11. Diagram Kepercayaan Pengguna terhadap Aplikasi

Pada Gambar.11 terdata skala 4.1 pada butir pernyataan "saya merasa percaya diri selama menggunakan aplikasi ini" dengan skala rata-rata 4.1 maka dinyatakan pengguna setuju dengan pernyataan kepesecayaan diri selama pengguna mengoperasikan media pembelajaran.

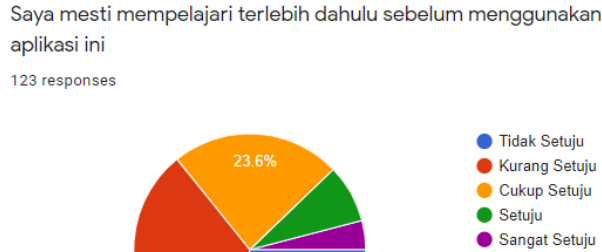

- Tidak Setuju

- Sangat Setuju

Gambar 12. Diagram Pengguna Membutuhkan Waktu Belajar

Pada Gambar 12 terkait dengan penyataan "saya mesti mempelajari terlebih dahulu sebelum menggunakan aplikasi ini”, memperoleh skala penilaian rata-rata dari pengguna sebesar 2.2 yaitu pengguna kurang setuju jika harus meluangkan waktu khusus untuk mempelajari sebelum menggunakan media pembelajaran Bahasa inggris, dikarenakan media pemebelajaran dirasa mampu untuk dioperasikan dengan mudah tanpa harus mempersiapkan waktu khusu untuk belajar.

\section{B. Hasil Penyebaran Kuesioner, Metode Kualitatif}

Berikut penjelasan hasil penyebaran kuesioner dengan penerapan metode kualitatif user interface media pembelajaran Bahasa inggris berlandaskan pada 10 prinsip dan pernyataan pada evaluasi heuristik.

1) Visibilitas Status Sistem, melakukan pengujian terhadap sistem terkait pada pemberian informasi kepada pengguna mengenai apa yang sedang terjadi saat ini dengan melalui pesan feedback yang baik dan tepat. Terkait pada pernyataan pertama pada evaluasi heuristic dirangkum dalam lima tanggapan pengguna pada umumnya merasa:
- Untuk feedback dari game itu menurut saya sudah baik, halhal kecil seperti hover mouse pada tulisan yang kemudian memberikan warna lain, dan text yang telah berhenti berarti dapat diklik untuk melanjutkan. Contoh pernyataan tersebut bisa dilihat pada Gambar.13, pada tombol "preferences" dengan feedback warna biru Ketika hover mouse dilakukan oleh pengguna selama mengakses media pembelajaran tersebut.

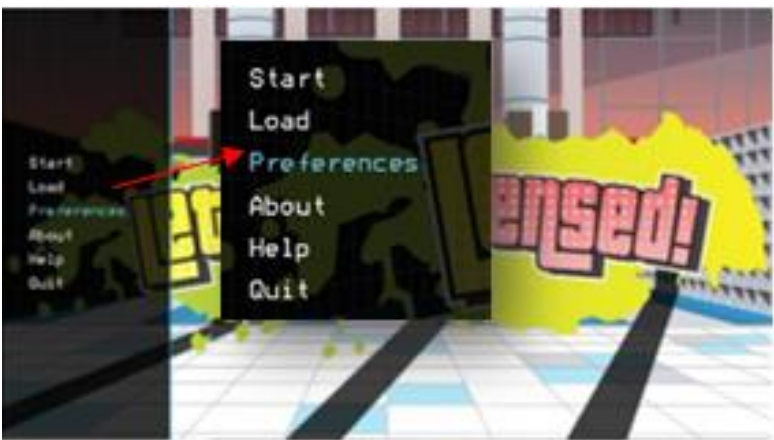

Gambar 13. Feedback mouse hover dan warna tombol pilihan

- Sistem feeedback yang diberikan kepada pengguna sudah baik karena sudah menjelaskan kepada user jika ada jawaban yang salah dan benar pada saat pengguna menjawab pertanyaan kuis pada media pembelajaran. Contoh feedback yang diberikan oleh aplikasi Ketika pengguna mengalami kesalahan dalam menjawab kuis.

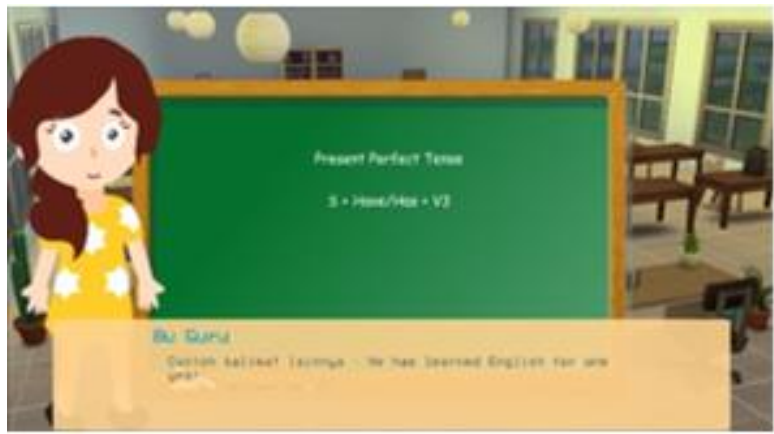

Gambar 14. Feedback bagi pengguna melakukan kesalahan

- Untuk pesan feedbacknya sudah bagus karena ada interaksi antara pengguna dengan sistem yang mana jika si pengguna tidak mengerti ada pesan feedback untuk mengulang penjelasan, yang dapat dilihat pada Gambar 15 ketika pengguna mengoperasikan media pembelajaran 


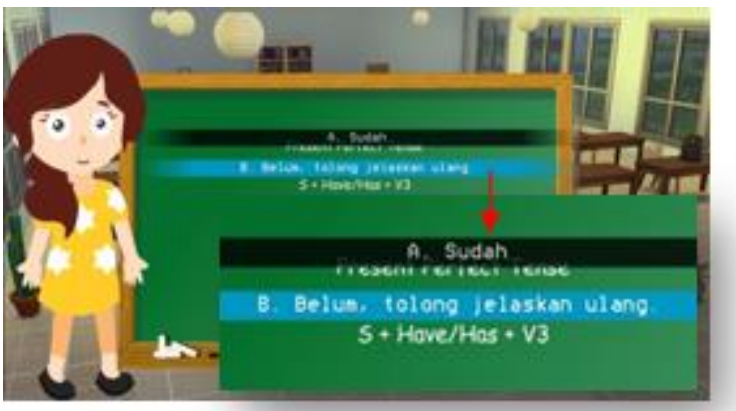

Gambar 15. Feedback pilihan pengguna sudah/belum mengerti

- Terdapat feedback kepda pengguna ketika berhasil menjawab pertanyaan kuis dengan benar dan dinyatakan "congrats" dan bagi pengguna yang menjawab salah akan diberikan feedback "fail". Pada Gambar 16 contoh feedback yang diberikan media pembelajaran ketika berhasil atau benar menjawab semua pertanyaan (sesuai dengan jumlah soal, maka mempunyai poin kelulusan yang telah ditentukan media pembelajaran), maka akan muncul feedback berupa "congratulations".

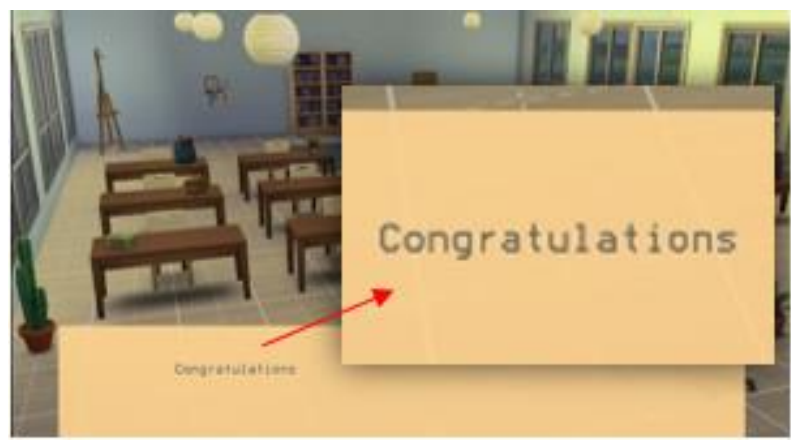

Gambar 16. Feedback yang muncul ketika pengguna berhasil

Feedback yang diberikan pada media pembelajaran jika pengguna salah menjawab pertanyaan kuis maka akan muncul "kamu salah" dan jika dijawab salah berturut-turut maka akan muncul feedback pernyataan "fail" pada media pembelajaran yang menandakan bahwa pengguna harus mengulang materi pelajaran hingga mengerti dengan baik.

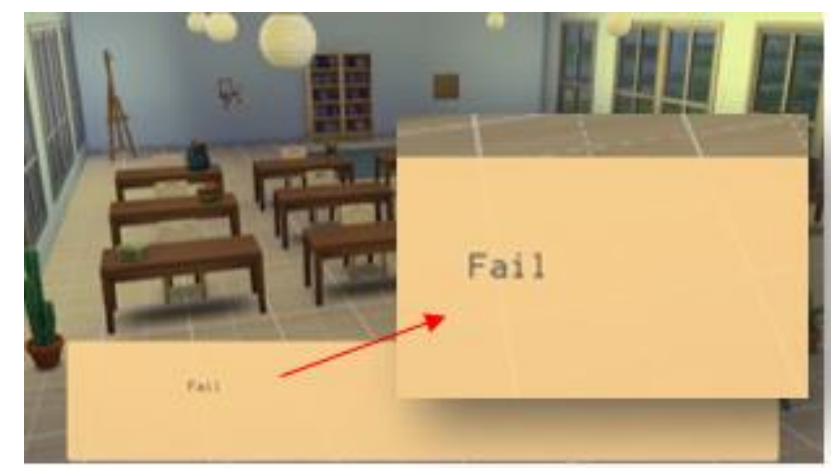

Gambar 17. Feedback yang muncul ketika pengguna gagal
- Feedback sudah sangat bagus dan tidak ada error atau kesalahan. Jika ada pilihan dan dijawab salah ada sound effect dan getaran jika benar akan lanjut. Bagian ini media pembelajaran memiliki fitur menggetarkan layar ketika pemngguna menjawab salah pertanyaan kuis, sehingga mampu memberikan peringatan pada pengguna bahwa jawaban tersebut salah.

2) Kecocokan antara sistem dengan dunia nyata, yaitu sistem mampu berbicara dengan pengguna dengan menggunakan kalimat dan bahasa yang mudah dimengerti dan sesuai dengan konsep pengguna. Terkait pada pernyataan kedua pada evaluasi heuristic dirangkum dalam lima tanggapan pengguna pada umumnya merasa:

- Menurut saya sudah cocok gambar, lagu dan cerita yang digunakan dengan dunia nyata

- Menurut saya sistem tersebut sudah sangat sesuai dengan dunia nyata sehingga mudah dimengerti bagi pengguna. Karena bahasa yang digunakan itu bahasa sehari hari yang diemukan, tidak ada pembuatan kata baru dalam aplikasi tersebut.

- Sudah baik, karena dengan sistem dapat mengerti dan sesuai dengan konsep pengguna maka pengguna akan merasa nyaman sehingga bisa membuat pengguna betah menggunakan media pembelajaran tersebut lebih sering.

- Menurut saya, sudah cocok karena bahasa yang mudah dimengerti oleh manusia serta sistem nya mampu berbicara dengan pengguna karena secara tidak sengaja dirasakan seolah olah pengguna adalah karakter yang ada di dalam game tersebut, tentu berinteraksi dengan ketersediaan interface yang userfriendly.

- Menurut saya, sistem ini sudah mampu membuat user berinteraksi dengan sistem. Dimana di dalam sistem akan disampaikan beberapa pertanyaan kepada user, dan kami sebagai user harus menjawab pertanyaan-pertanyaan itu agar jalan ceritanya dapat dilanjutkan.

Berikut contoh user interface media pembelajaran dengan menggunakan Bahasa interaksi yang mudah dimengerti sesuai dengan konsep pengguna, dengan kata lain user interface yang digunakan mampu disajikan sesuai dengan kriteria userfriendly. 


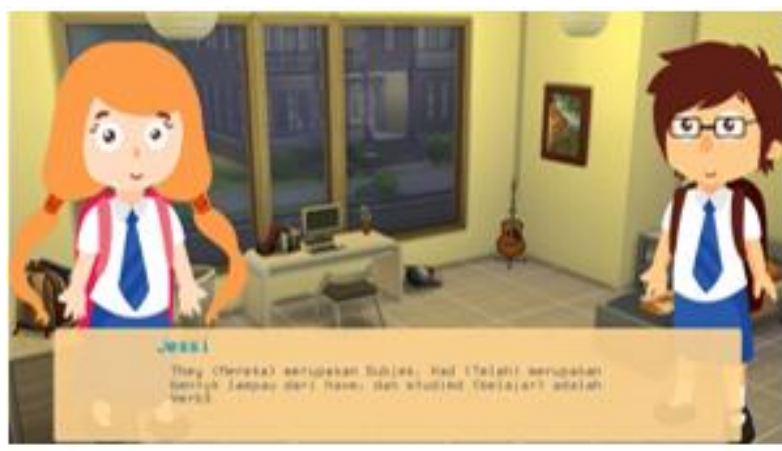

Gambar 18. Penggunaan Bahasa yang userfriendly

3) Kontrol pengguna dan kebebasan, menguji sistem apakah mampu memberikan pengguna rasa bebas dalam memilih dan melakukan pekerjaan sesuai dengan kebutuhan hingga tahap pengguna mampu melakukan kontrol lanjut dan kembali selama penggunaan sistem. Terkait pada pernyataan ketiga pada evaluasi heuristic dirangkum dalam lima tanggapan pengguna pada umumnya merasa:

- Untuk settings pada saat dalam game atau sedang di dialog bisa ditambahkan setting control untuk melihat hotkeynya.

- Pengguna bisa mengatur apa saja yang dinginkan seperti musik, voice, size layer dan sebaginya yg tersedia.

- Dalam hal ini, saya sudah merasa lengkap dalam game tersebut, dimana kontrol button yang terdapat dalam applikasi tersebut memiliki tombol lengkap, terutama dari settingnya sesuai dengan kebutuhan pengguna.

- Untuk kontrol pengguna dan kebebasan ini sendiri sudah cukup membantu, dimana kami sebagai user bisa mengatur apa yang diperlukan user di pilihan Option. Mungkin di beberapa kasus, ada user yang memang masih belum terbiasa untuk membaca text secara cepat, maka di sini user bisa mengatur Speed Text yang akan muncul sesuai keinginan user sendiri.

- Kontrol aplikasi Bahasa Inggris menggunakan settings yang sangat banyak pilihannya, seperti mengecilkan window atau fullscreen dan sebagainya.

Berikut penyajian kebebasan control pengguna terhadap media pembelajaran selama penggunaan.

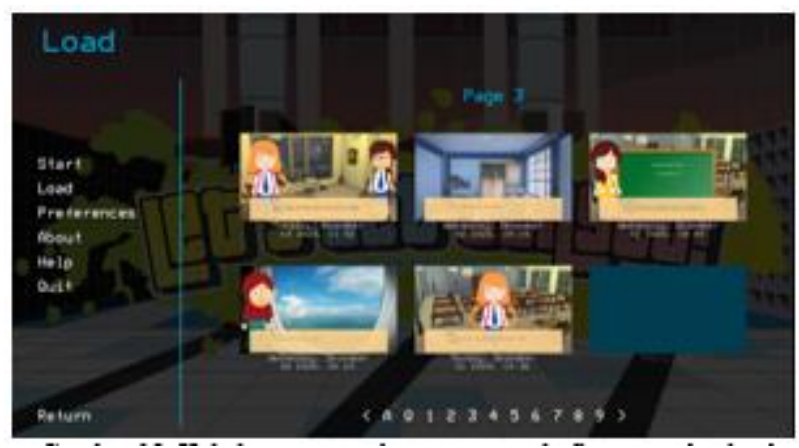

Gambar 19. Kebebasan control pengguna pada fitur save dan load
Pada Gambar 20, menyajikan user interface dengan fitur pendukung kebebasan pengguna dalam mengkontrol kebutuhan selama menggunakan media pembelajaran.

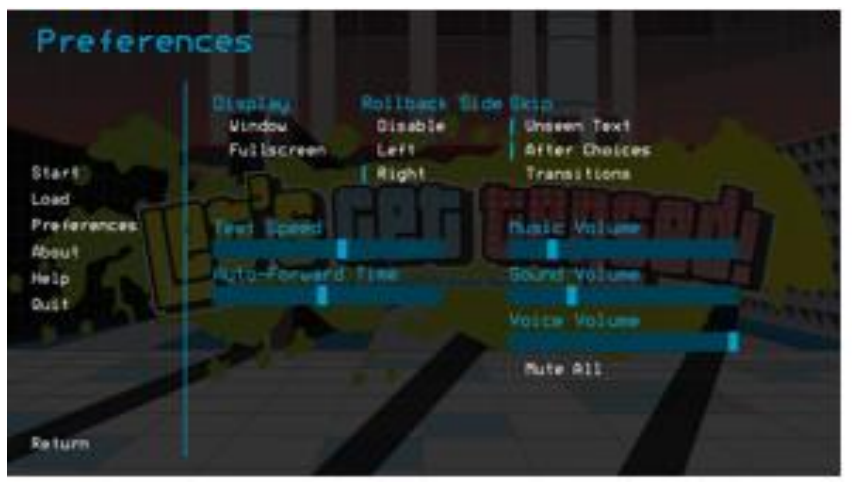

Gambar 20. Kebebasan control pengguna pada fitur preferences

Pada Gambar 20, penyajian pada control terhadap kebebasan pengaturan pengguna pada model layout media pembelajaran, pengaturan suara dan music, dan kecepatan teks pada tampilan visual novel selama pengguna mengoperasikan.

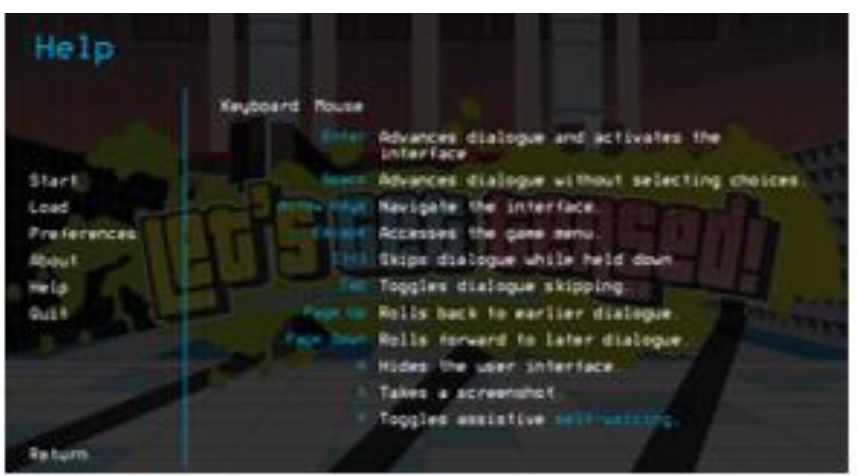

Gambar 21. Kebebasan control pengguna dengan hotkeys

Penyajian pada gambar 21 terhadap kebebasan control pengguna selama berada dalam media pembelajaran bebas control dengan beberapa hotkeys atau shortcut pengaturan layar media pembelajaran tersebut.

4) Konsistensi dan Standar, konsisten dalam tampilan sehingga mampu meminimalisir keraguan pengguna selama menggunakan sistem. Terkait pada pernyataan keempat pada evaluasi heuristic dirangkum dalam lima tanggapan pengguna pada umumnya merasa:

- Untuk tampilannya sudah konsisten dari pewarnaannya dan juga pemilihan font tulisannya.

- Konsistensi dan standar dalam tampilan aplikasi tersebut memang sudah ada dan bagus, sehingga pengguna juga dapat menjalankan aplikasi tersebut dengan lancar, pemilihan warna dan desain sesuai dengan tema aplikasi. 
- Untuk konsistensi pada jalan cerita aplikasinya sudah konsisten dimana peletakkan karakter, text box, dan sebagainya dari setiap section sudah rapi.

- Sangat konsisten, mulai dari main menu dengan jenis font dan warna yang sama, dan dari sisi in game juga peletakkan kotak dialog, ukuran font, jenis font, dan lainlain sudah sangat konsisten begitu juga dengan penempatan karakternya.

- Sudah konsisten karena tataan tombol pada main menu (Start, Load, Preferences, About, Help, Quit) sudah konsisten dengan urutan tombol main menu di game lain sehingga user dapat langsung mengerti tanpa melihat isi tombol pada main menu.

Komentar pengguna terhadap display pada media pembelajaran yang konsisten terhadap pemilihan warna, karakter, bentuk tulisan, penempatan karakter dan tombol pilihan pengguna selama menggunakan media pembelajaran Bahasa inggris visual novel tersebut.

5) Pengecekan kesalahan, sebuah sistem yang dianggap baik adalah yang mampu membuat pengguna dalam menghindari sebuah kesalahan salama penggunaan sistem, maka pencegahan dalam kesalahan sistem sangat perlu diperhatikan sebelum dan selama pengguna menggunakan sistem tersebut. Terkait pada pernyataan kelima pada evaluasi heuristic dirangkum dalam lima tanggapan pengguna pada umumnya merasa:

- Sudah terdapat pengecekan kesalahan dalam visual novel ini, yaitu saat menekan tombol quit, sistem akan menanyakan user "are you sure?".

- Terdapat panel warning yang dapat mencegah pengguna dari salah menekan suatu tombol misalnya pada Save.

- Dalam game ketika salah memberikan jawaban pada kuis akan memberikan feedback bahwa jawaban yang pengguna berikan itu salah.

- Untuk membuat pengguna dalam menghindari sebuah kesalahan selama penggunaan sistem sudah ada di bagian Help di main menu aplikasi. Dimana sudah ditampilan dengan jelas kegunaan tombol-tombol yang dibutuhkan.

- Cukup baik karena pengecekan kesalahannya sudah sangat akurat di berikan kepada pengguna sesuai dengan kondisi saat pengguna menemukan masalah.

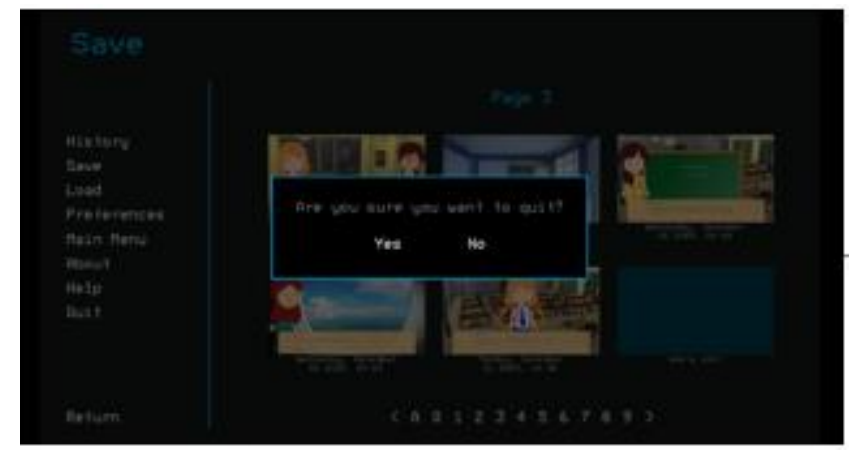

Gambar 22. Tampilan pengecekan kesalahan pada aplikasi

Pada gambar 22, menyajikan salah satu contoh pengecekan kesalahan untuk menghindari kesalahan pada pengguna selama mengoperasikan media pembelajaran. Dilain sisi media pembelajaran juga menyajikan pengecekan kesalahan berupa fitur suara dan getar selama pengguna salah menjawab soal kuis dan akan memberikan feedback kesalahan tersebut.

6) Pengenalan atas penarikan kembali, pengguna tidak ragu dan bingung terhadap pemahaman kalimat, kata maupun sebuah aksi dalam sistem. Terkait pada pernyataan keenam pada evaluasi heuristic dirangkum beberapa tanggapan pengguna pada umumnya diantaranya merasa:

- Pada alur yang linear, dan beberapa bagian dengan looping yang dapat dipahami (seperti Fail saat quiz, maka mengulang) maka pengguna dapat gampang memahami aksi-aksi tersebut.

- Untuk pengenalan atas penarikan kembali terhadap pemahaman kalimat ini cukup bagus, dimana sebagai user ketika sudah menyelesaikan materi (Contoh: Past Tense) akan ditanyakan kembali apakah user sudah mengerti atau belum. Jika user belum memahami materi yang telah disampaikan, user dapat mengulangi materinya kembali dengan memilih pilihan kedua. Dimana ini sangat membantu user dalam menguasai sebuah materi.

- Untuk penarikan kembali, menurut saya cukup. karena saat pengguna tidak sengaja klik dan tidak bisa balik lagi pada dialog sebelumnya, namun pada saat sesudah penjelasan ditambahkan sebuah tombol yang menanyakan apakah sudah paham atau belum. sehingga user juga dalam mengulanginya kembali. 


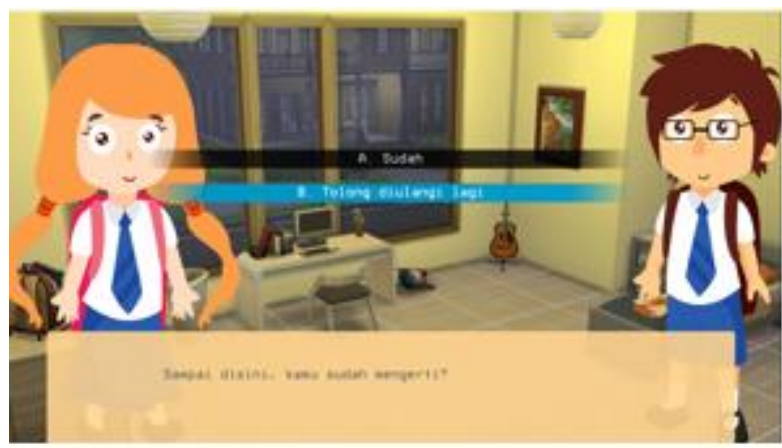

Gambar 23. Salah satu contoh penarikan Kembali bagi pengguna

Pada gambar 23, pengguna bebas mendapatkan penarikan Kembali terhadap aksi yang telah dilakukan selama belajar menggunakan media viual novel tersebut. Kemampuan fitur mengulang kembali dinilai mampu membantu pengguna mengulang ketika terjadi kesalahan mengklik pilihan menu.

7) Fleksibilitas dan efisiensi, sebuah sistem mampu dijadikan sebagai akomodasi pengguna yang sudah ahli maupun pengguna pemula. Sehingga diperlukan adanya ketegori pengguna. Terkait pada pernyataan ketujuh pada evaluasi heuristic dirangkum dalam lima tanggapan pengguna pada umumnya merasa:

- Untuk desain UI dari visual novel ini, menurut saya sudah cukup fleksibel bagi user, terutama bagi mereka yang baru saja pertama kali memainkan visual novel. Karena ada beberapa fitur seperti "Text-speed" dan "Automatic scroll text" yang memang spesifik terdapat pada visual novel dan memang memerlukan adaptasi atau perkenalan sebelumnya terlebih dahulu pada game visual novel. Tetapi selain itu semuanya sudah termasuk umum.

- Sudah cukup fleksibel, setelah di coba aplikasinya mudah di gunakan hanya dengan mengikuti tutorial awal tersebut, bisa juga di tambahkan peringatan dalam dialog dengan simbol enter untuk mempercepat.

- Menurut saya, aplikasi ini dari fitur tombolnya lumayan fleksibel digunakan terutama untuk orang-orang yang sering memegang teknologi sehingga applikasi ini mudah dioperasikan oleh user. Applikasi ini juga lumayan fleksibel dan efisien untuk orang-orang awam, alasannya karena dengan tombol fitur yang lengkap dan juga ada petunjuk seperti help untuk membantu user.

- Menurut saya aplikasi game ini sangat fleksibel, dapat digunakan oleh orang yang sudah ahli maupun tidak, karena aplikasi game ini digunakan sebagai pembelajaran, dimana yang ahli pun masih dapat memainkannya dan yang masih pemula dapat belajar hingga mengerti.
- Visual novel ini menurut saya, sangat fleksibel, karena user dapat mengubah settings sesuai dengan preferensi mereka, selain itu, button prompt-nya dapat diubah sesuai dengan preferensi mereka.

Terkait dengan pernyataan keenam pada evaluasi heuristic dinyatakan media pembelajaran bersifat fleksibel dinilai pada ketersediaan fitur dan kebeasan pengaturan pengguna selama mengoperasikan media pembelajaran tersebut.

8) Keindahan dan desain minimalis, sebuah sistem mampu menampilkan dan memberikan informasi dan pesan yang relevan terhadap kebutuhan pengguna. Terkait pada pernyataan kedelapan pada evaluasi heuristic dirangkum dalam lima tanggapan pengguna pada umumnya merasa:

- Untuk desain minimalis dari UI sudah bagus kerena tidak menampilkan terlalu banyak objek sekaligus dalam satu layar sehingga pengguna dapat berfokus pada materi yang disampaikan.

- Sudah baik, karena animasi yang berbentuk anak pelajar dan background yang sangat selaras dengan target penggunanya.

- Tampilan yang simpel tetapi pemilihan warna yang sangat menarik membuat aplikasi ini menjadi gampang untuk dioperasikan pengguna.

- Sudah sangat bagus. Tampilan aplikasi dari background, karakter tersebut sangat baik dan indah. Serta desain aplikasi tersebut juga sederhana namun sangat efektif. Sehingga dapat pesan dan informasi kepada user efektif dan efesien.

- Menurut saya, estetika untuk visual novel ini bagus, dari penggunaan font untuk textnya, penggunaan warna dan desain untuk main menu sudah lumayan bagus, karakter desainnya bagus dan simple, dan background yang digunakan cocok untuk scenario-scenarionya.

Penerapan desain yang minimalis dan indah pada media pembelajaran Bahasa inggris visual novel dianggap sudah baik, dikarenakan dengan dukungan desain karakter dan background yang bisa memberikan informasi tambahan mengenai dimana dan kapan scene tersebut berlangsung.

9) Bantuan bagi pengguna untuk mengenali, mendiagnosis dan memperbaiki dari kesalahan. Dengan menunjukkan sebuah masalah yang muncul dan mampu memberikan saran sebuah solusi bagi pengguna. Terkait pada pernyataan kesembilan pada evaluasi heuristic dirangkum dalam lima tanggapan pengguna pada umumnya merasa: 
- Ada bantuan bagi pengguna. Penerapan standar yakni save and load, serta kemampuan untuk retry.

- dari pengujian aplikasi yang sudah dilakukan, untuk bantuan untuk mengenali dan semacamnya sudah sangat bagus karena sistem-nya bisa memberikan pengguna sebuah feedback bila ada suatu kesalahan.

- bantuan perbaikan kesalahan dari game ini cukup baik karena dapat memberikan informasi dengan baik.

- Menurut saya sudah bagus karna ada penjelasan tentang tensesnya dan ada pemilihan untuk membaca ulang penjelasannya saran saya menambahkan kayak library gitu yg dimana semua penjelasan tenses di game itu ada di bagian library.

- Sudah baik, seperti pada bantuan bagi pengguna ketika mendapatkan sebuah feedback dari suara dan kalimat sehingga pengguna akan mengerti dan bisa memperbaiki kesalahan.

Pada poin pernyataan kesembilan terkait dengan bantuan pengguna mengenali kesalahan dinilai mampu dan telah dirancang pada game visual novel pembelajaran Bahasa inggris ini dengan cukup detail, dengan tujuan lain agar pengguna tidak kebingungan selama mengoperasikan aplikasi dan tentu ketika pengguna mendapatkan kesalahan pada menjawab pertanyataan maupun kesalahan klik tombol menu yang mungkin terjadi selama dalam media pembelajaran.

10)Bantuan dan dokumentasi, sistem yang baik dianggap perlu adanya sebuah pedoman bagaimana mengoperasikan sistem, sehingga mampu membantu pengguna mempelajari sistem secara mandiri dengan cepat dan mudah. Terkait pada pernyataan kesembilan pada evaluasi heuristic dirangkum dalam lima tanggapan pengguna pada umumnya merasa:

- Dari segi tampilan bantuan maupun dokumentasi sudah ada pada menu utama sebelum pengguna bermain game tersebut sudah ada tombol help.

- Tombol bantuan pada apliaksi terdapat pada menu utama sehingga pemain yang bingung dapat langsung menekan tombol bantuan. Tombol simpan juga sudah sangat baik karena aplikasi akan menanyakan terlebih dahulu kepada user apakah progress dri pemain ingin di simpan atau tidak

- Bantuan atau help dalam aplikasi game tersebut cukup dimengerti karena penjelasannya yang simple dan langsung ke inti dari persoalannya.

- bagian save atau dokumentasi sudah sangat jelas dan ada banyak save slot untuk menghindari pengguna aplikasi yang tiba-tiba mati lampu, dan sebagainya.
- Sudah baik, pada game di berikan beberapa tombol keyboard beserta fungsinya, namun lebih baik jika fungsi tombol diberikan saat awal tampilan game, sehingga user juga dapat lebih paham tentang tombol pada keyboard.

Pada poin pernyataan kesepuluh terkait pada bantuan dan dokumentasi, pengguna aplikasi menyatakan media pembelajaran telah menyediakan tombol bantuan dan dokumentasi (load) dengan baik dan lengkap dan disini dinilai mampu membantu pengguna selama mengoperasikan aplikasi

\section{KESIMPULAN}

Penelitian ini berfokus terhadap desain antarmuka pada media pembelajaran Bahasa inggris berbasis visual novel, dalam penelitian ini berlandaskan pada sepuluh poin besar evaluasi heuristic dengan penerapan mixed method analisis kuantitatif dan kualitatif dalam pengujian antarmuka yang telah dirancang. Dari hasil penelitian yang telah dilakukan pada layout antarmuka maka diperoleh kesimpulan beberapa temuan sebagai berikut:

1. Keseluruhan dari pengujian pertama dengan prinsip pertanyaan pada usability testing pada fokus penerapan analisis kuantitatif didapatkan poin pengujian rata-rata dengan nilai 4, dinilai desain layout antarmuka media pembelajaran setuju diterima oleh pengguna dalam penerapannya.

2. Keseluruhan dari pengujian kedua dengan prinsip sepuluh pernyataan pada evaluasi heursitik terhadap fokus penerapan analisis kualitatif didapatkan rata-rata penilaian pengguna pada layout antarmuka media pembelajaran visual novel Bahasa inggris dengan kesimpulan mereka setuju pada setiap bobot poin pernyataan yang diujikan.

3. Didapatkan beberapa masukan kedepannya terhadap desain layout antarmuka media pembelajaran agar dirancang dalam bentuk karakter dan antarmuka berbasis tiga dimensi, yang bertujuan agar mampu menarik lebih banyak minat pengguna untuk menggunakan aplikasi.

4. Berdasarkan pada penelitian yang dilakukan didapatkan bahwa struktur dalam desain user interface media pembelajaran berbasis game visual novel terdapat halaman menu utama, materi mencakup hingga kuis interaktif yang mampu menciptakan fungsional yang baik sehingga menciptakan pengalaman (user experience) bermain sambal belajar pengguna yang lebih baik.

\section{UCAPAN TERIMA KASIH}

Ucapan terima kasih saya sampaikan kepada beberap pihak terkait:

1. Kampus Universitas Internasional Batam (UIB), Rektor dan segenap Civitas Akademik serta Biro LPPM UIB yang telah banyak membantu proses penulisan penelitian dan dukungan baik secara moril maupun materi. 
2. Tim Surveyor yang membantu peneliti dalam proses pengumpulan data hingga tahap pengolahan data didapatkan dengan hasil yang memuaskan yaitu kepada Nurul Asmawati dan Marilyn Fu yang juga berperan aktif menjadi rekan peneliti dalam membantu pengembangan proyek hingga selesai.

\section{DAFTAR PUSTAKA}

[1] M. N. El Ghiffary Et Al., "Analisis User Experience Pada Game Cs:Go Dengan Menggunakan Metode Cognitive Walkthrough Dan Metode Heuristic Evaluation," J. Pengemb. Teknol. Inf. Dan Ilmu Komput., Vol. 8, No. 3, Pp. 212-219, 2017, Doi: 10.12962/J23373539.V7i1.28723.

[2] L. L. Shidqi, V. Effendy, And A. Herdiani, "Model User Interface Aplikasi Pembelajaran Doa-Doa Harian Sesuai User Experience Anak Usia Dini Menggunakan Metode User Centered Design," EProceeding Eng., Vol. 4, No. 3, Pp. 4866-4873, 2017.

[3] Y. M. Geasela, P.- Ranting, And J. F. Andry, "Analisis User Interface Terhadap Website Berbasis E-Learning Dengan Metode Heuristic Evaluation,” J. Inform., Vol. 5, No. 2, Pp. 270-277, 2018, Doi: 10.31311/Ji.V5i2.3741.

[4] N. Ratnasari And A. P. Wibawa, "Analisis Perbandingan Kualitas Ui/Ux Platform Online Coding Course Pada Pembelajaran Daring Pemrograman Komputer Dengan Metode A/B Testing," J. Edukasi Dan Penelit. Inform., Vol. 6, No. 2, P. 210, 2020, Doi: 10.26418/Jp.V6i2.40771.

[5] W. W. N. Rahina, "Jurnal Imajinasi," J. Imajin., Vol. Xii, No. 2, Pp. 57-64, 2018

[6] M. Damayanti, A. Aziz, And M. Ahsan, "Penerapan User Centered Design Dengan Pendekatan Uji Usability Pada Perancangan," Vol. 2, 2019.

[7] W. H. Nunung Dwi Supriyono, Abdul Aziz, "Analisis User Interace Dan User Experience Pada Game Perang Komando Menggunakan Metode Heuristic Evaluation," Vol. 2, No. 1, P. 100, 2019.

[8] A. R. Hidayat And E. Junianto, "Pengaruh Gadget Terhadap Prestasi Siswa Smk Yayasan Islam Tasikmalaya," J. Inform., Vol. 4, No. 2, Pp. 163-173, 2017.

[9] S. Sholiqah And R. Agustina, "Pengembangan Media Pembelajaran Animasi 3d Sistem Anatomi Tubuh Manusia," Vol. 2, Pp. 453-463, 2019.
[10] M. Bahariyani And I. S. Widiati, "Analisis Desain Antarmuka Portal Pembelajaran Online Menggunakan Evaluasi Heuristik," Vol. 6, No. 1, Pp. 10-20.

[11] U. Ependi, T. B. Kurniawan, And F. Panjaitan, "System Usability Scale Vs Heuristic Evaluation: A Review," Simetris J. Tek. Mesin Elektro Dan Ilmu Komput., Vol. 10, No. 1, Pp. 65-74, 2019, Doi: 10.24176/Simet.V10i1.2725.

[12] D. U. Hidayah, I. R. Yunita, And G. Setyaningsih, "Evaluasi Website Kuliah Online Stmik Amikom Purwokerto Menggunakan Metode Heuristik (Studi Kasus Mata Kuliah Enterprise Resource Management)," Matrik J. Manajemen, Tek. Inform. Dan Rekayasa Komput., Vol. 18, No. 2, Pp. 171-179, 2019, Doi: 10.30812/Matrik.V18i2.360.

[13] W. Handiwidjojo And L. Ernawati, "Pengukuran Tingkat Ketergunaan (Usability) Sistem Informasi Keuangan Studi Kasus : Duta Wacana Internal Transaction (Duwit)," Juisi J. Inform. Dan Sist. Inf., Vol. 02, No. 01, Pp. 49-55, 2016, [Online]. Available: Https://Journal.Uc.Ac.Id/Index.Php/Juisi/Article/View/115.

[14] N. Dalimunthe, A. Dawiyah, F. Nazari, And K. Purba, "Evaluasi Website Pemko Pekanbaru Menggunakan Metode Heuristic Evaluation," J. Ilm. Rekayasa Dan Manaj. Sist. Inf., Vol. 5, No. 2, P. 245, 2019, Doi: 10.24014/Rmsi.V5i2.7538.

[15] J. Raco, "Metode Penelitian Kualitatif: Jenis, Karakteristik Dan Keunggulannya," 2018, Doi: 10.31219/Osf.Io/Mfzuj.

[16] N. Arifiati, "Analisis Faktor Yang Mempengaruhi Pemberian Asi Ekslusif Pada Bayi Di Kelurahan Warnasari Kecamatan Citangkil Kota Cilegon," J. Pros. Semin. Nas. Ikakesmada "Peran Tenaga Kesehat. Dalam Pelaks. Sdgs,” Pp. 129-125, 2017, [Online]. Available: Http://Eprints.Uad.Ac.Id/5411/1/18. Analisis Faktor Yang Mempengaruhi Pemberian Asi Ekslusif Pada Bayi Di Kelurahan Warnasari Kecamatan Citangkil Kota Cilegon.Pdf.

[17] L. Putu And G. Cahyani, "E-Jurnal Akuntansi Universitas Udayana Pengaruh Tarif Pajak, Pemahaman Perpajakan, Dan Sanksi Perpajakan Fakultas Ekonomi Dan Bisnis Universitas Udayana ( Unud ), Bali , Indonesia Pendahuluan Pajak Merupakan Salah Satu Target Utama Pemerintah Yang Dijad," Vol. 26, Pp. 1885-1911, 2019.

[18] M. Setiono And R. Riwinoto, "Analisa Pengaruh Visual Efek Terhadap Minat Responden Film Pendek Eyes For Eyes Pada Bagian Pengenalan Cerita (Part 1) Dengan Metode Skala Likert," J. Komput. Terap., Vol. 1, No. 2, P. 169334, 2015. 